\title{
COMPETITIVE TENDERING: FAKTOR TERJADINYA INSOLVENCY PADA PERUSAHAAN KONSTRUKSI (SEBUAH LITERATUR)
}

\author{
Ipak Neneng Mardiah Bukit ${ }^{1}$ \\ ${ }^{1)}$ Prodi Teknik Sipil, Fakultas Teknik, Universitas Samudra \\ Jalan Kp Meurandeh, Kecamatan Langsa Lama, Kota Langsa, \\ email: ipak_neneng@yahoo.com
}

\begin{abstract}
The construction industry is a vanguard in developing countries, including Indonesia. It has unique characteristics where complex works exist. These characteristics distinguish this industry from other industries in economy. Its project involves so many risks that have potentially business failure. Failure, bankruptcy or insolvency is unpleasant words, but people in the industry cannot ignore them. This paper thoroughly explored the causes of insolvency in Construction Company due the procedure of competitive tendering in Indonesia and how to avoid it. Insolvency in Indonesia is caused by lack of business experiences, country's economic condition, poor control of cash flow, cannot convince clients, and low profit margin as a result of competitive tendering. Some researchs found that insolvency can be predicted at early opportunity, and some methods are applied to prevent insolvency.
\end{abstract}

Key words: Construction Industry, Contractors, Competitive Tendering, Failure, Insolvency

\begin{abstract}
Abstrak: Industri konstruksi merupakan industri perintis di negara-negara berkembang, termasuk Indonesia. Setiap industri konstruksi memiliki karakter yang unik dimana banyak melibatkan pekerjaan yang sulit dan kompleks. Karakter dari industri konstruksi membedakannya dari industri di bidang lainnya seperti produksi pabrik (manufacturing). Proyek konstruksi melibatkan banyak resiko (risks) yang dapat berpotensi membawa perusahaan kepada kegagalan usaha (business failure). Kegagalan (failure), kebangkrutan (bankruptcy ataupun insolvency) adalah kata-kata yang tidak menyenangkan, akan tetapi orang yang bekerja di industri ini tidak boleh mengabaikannya. Tulisan ini akan mengupas secara menyeluruh penyebab insolvency pada perusahaan konstruksi akibat dari prosedur pelelangan kompetitif di Indonesia dan bagaimana menghindarinya. Setelah diteliti dengan baik, insolvency di Indonesia disebabkan oleh kurangnya pengalaman dalam bisnis konstruksi, kondisi ekonomi dalam negeri, kurangnya kemampuan pengendalian aliran uang dalam perusahaan, tidak adanya kemampuan untuk meyakinkan klien dan rendahnya nilai profit yang ditetapkan sebagai upaya untuk memenangkan tender. Penelitian yang pernah dilakukan menemukan bahwa insolvency dapat diketahui lebih dini dan beberapa metode dapat diterapkan dalam upaya menghindarinya.
\end{abstract}

Kata kunci: Industri konstruksi, kontraktor, tender kompetitif, kegagalan, insolvency

\begin{abstract}
Industri konstruksi di Indonesia sangatlah penting untuk memenuhi kebutuhan infrastruktur. Perusahaan konstruksi menjadi ujung tombak dalam industri ini, yang menyebabkan corporate sustainability (keberlangsungan usaha) harus
\end{abstract}

menjadi perhatian utama. Berbagai macam permasalahan yang dihadapi di Indonesia pada industri ini adalah seperti jumlah perusahaan yang terdaftar lebih besar dari jumlah pekerjaan yang ditawarkan pemerintah maupun swasta, tidak adanya 
kemampuan manajemen dan pengalaman keteknikan dikaitkan dengan kualifikasi teknik terhadap pengaturan sumber daya dan persiapan tender. Walaupun LPJK (Lembaga Pengembangan Jasa Konstruksi) mengesahkan kualifikasi dari perusahaan konstruksi sebelum mereka dapat mengajukan penawaran pada sebuah tender, tetap saja banyak perusahaan yang kurang berkualitas.

Lebih jauh lagi, ketergantungan terhadap proyek-proyek yang berbasis pemerintah, membuat pelelangan kompetitif menjadi tidak proporsional keberadaannya. Praktek kecurangan (non-technical factors) dapat menyebabkan kemungkinan insolvency pada perusahaan konstruksi di Indonesia. Sebagai contoh, bangkrutnya PT Istaka Karya pada tahun 2011 disebabkan oleh faktor non teknis (Saputra, 2011), dimana mereka tidak mampu membayar hutang total sebesar US\$ 7.6 juta kepada PT Japan Asia Investment Company.

Industri konstruksi memiliki banyak karakteristik yang unik. Raftery (1997) seperti dikutip oleh Al Hallaq (2003) menjelaskan bahwa industri konstruksi mempunyai kecendrungan atau reputasi atas keterlambatan waktu dan kelebihan biaya pelaksanaan (time and cost overrun). Proyek konstruksi selalu rumit dimana melibatkan sejumlah besar aspek yang harus dapat dikendalikan dan diatur dengan baik. Aspekaspek ini diantaranya pekerjaan struktur keteknikan, keuangan/finansial, tenaga kerja, peralatan, jadwal pelaksanaan, dan juga aliran uang yang sangat ketat untuk dikontrol penggunaannya, dan semua aspek itu berkaitan pula dengan masalah makroekonomi dan/atau peraturan pemerintah dan juga prilaku dari pelaku bisnis sendiri.

Seluruh aspek yang ada dalam industri konstruksi ini membuat perusahaan yang bergerak di bidang ini sangat rentan terhadap kegagalan (failure). Resiko bisnis pada dasarnya ada pada semua industri, namun banyak perusahaan konstruksi tidak dapat bertahan oleh resiko yang mengarah kepada kegagalan ataupun insolvency. Al Hallaq (2003) mengutip dari Clough dan Sears (1994) yang mengatakan “ ...construction industry is one of the riskiest of all business types". Insolvency berarti kegagalan finansial dari individu atau perusahaan dan posisi mereka sebelum atau sesudah dimulainya prosedur formal insolvency (Fisk, 1997) seperti dikutip oleh Arain (2008). Tulisan ini akan mengeksplor lebih dalam mengenai konteks bagaimana pelelangan kompetitif (competitive tendering) dapat menyebabkan terjadinya insolvency pada perusahaan konstruksi di Indonesia dan mencari jawaban bagaimana menghindari terjadinya kegagalan bisnis pada industri ini.

\section{PENYEBAB TERJADINYA}

\section{INSOLVENCY}

Penelitian terdahulu menemukan bahwa tingkat kegagalan oleh perusahaan konstruksi (mulai saat ini disebut kontraktor) adalah lebih tinggi dari jenis perusahaan lainnya ( $\mathrm{Ab}$ Halim, 2010). Kegagalan adalah sebuah hasil 
dari proses yang rumit, bukan hanya dari satu faktor saja. Kivrak dan Arslan (2008) sebagaimana dikutip oleh Wong (2010) menjelaskan bahwa faktor kritis dari kegagalan pada kontraktor dapat disebabkan oleh tidak adanya pengalaman bisnis dan kondisi ekonomi dalam negeri. Tidak adanya pengalaman bisnis juga dapat mengakibatkan lemahnya pengendalian aliran uang (cash flow) perusahaan dan ketidakmampuan menarik klien-klien baru untuk perusahaan.

Banyak sekali kontraktor yang merupakan sub-kontraktor, mereka bekerja di bawah kontraktor yang lebih besar (maincontractors); sehingga mereka biasanya adalah perusahaan kecil dengan jumlah staf yang terbatas. Kebanyakan sub-kontraktor tidak memiliki departemen keuangan untuk mengendalikan aliran uang; sehingga untuk memonitor ratio finansial sedikit sulit dilakukan.

Schaufelberger (2003) seperti dikutip oleh Wong (2010) mempelajari bahwa salah satu penyebab dari kegagalan bisnis adalah pada level sub-kontraktor dengan penggunaan sistem akunting yang sangat lemah.

Kemampuan menarik minat bagi klien baru untuk mempekerjakan perusahaan juga sangat penting bagi kontraktor, karena klien adalah orang yang mampu memberikan keuntungan bagi perusahaan. Ketidakmampuan kontraktor untuk menarik minat klien tentunya akan menghilangkan keuntungan bagi perusahaan. Jika hal ini terjadi, hasilnya akan sangat tidak menyenangkan bagi perusahaan ke depannya, karena akan menyebabkan kegagalan atau insolvency.

Faktor kritis lainnya menurut Kivrak dan Arslan adalah kemampuan untuk mempersiapkan proposal tender yang akurat dan realistis.

Kangari (1988) sebagaimana dikutip oleh Wong (2010) mengatakan bahwa lebih dari setengah kegagalan bisnis di bidang konstruksi disebabkan oleh marjin profit yang tidak realistis. Lebih daripada itu, sebuah proposal tender yang proporsional dengan marjin profit yang realistis dinyatakan sebagai sangat kritikal (Arslan et al, 2006 seperti dikutip oleh Wong, 2010). Kontraktor dituntut untuk memenangkan tender dalam kompetisi yang ketat dan penampilan mereka dapat di observasi dari proposal tender mereka, jika dianggap rasional.

Dari penjelasan di atas, maka penyebab dari kebangkrutan perusahaan konstruksi dapat digambarkan sebagai berikut:

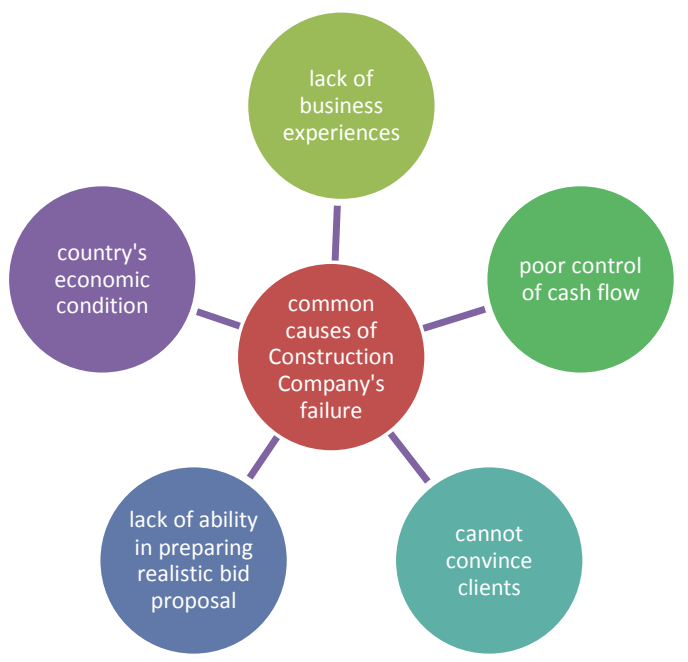

Gambar 1. Penyebab umum dari insolvency (kebangkrutan) 
PROSES TENDER KOMPETISI DI INDONESIA

Merujuk pada Perpres RI Nomor 54/2010 tentang Pengadaan Barang dan Jasa, “....pekerjaan konstruksi adalah seluruh kegiatan yang berhubungan dengan konstruksi bangunan atau segala struktur fisiknya." (Perpres, 2010).

Lebih jauh lagi, Perpres No. 54/2010 menjelaskan tentang tender sebagai berikut: Pelelangan kompetitif adalah suatu metode untuk mendapatkan penyedia/kontraktor/jasa lainnya untuk keseluruhan pekerjaan yang dapat ditawarkan oleh setiap penyedia barang/kontraktor/jasa lainnya yang dianggap memenuhi syarat dan kualitas. Peraturan tentang pengadaan ini mempunyai prinsip efisien, efektif, transparan, terbuka, kompetitif, adil/tidak diskriminatif dan bertanggung jawab (Perpres, 2010).

Proses tender di bidang pengadaan jasa merujuk pada peraturan pemerintah RI ini. Untuk mengajukan penawaran, kontraktor harus mendapat sertifikasi oleh LPJK. Kualifikasi ini diperlukan untuk memastikan kalau perusahaan tersebut mampu bekerja di bidang tertentu yang diperlukan oleh owner. LPJK akan mengeluarkan surat tentang jenis keahlian dan klasifikasi perusahaan tersebut. Sertifikasi dari LPJK yang disebut SBU (Sertifikat Badan Usaha) diperlukan oleh perusahaan untuk mendapatkan IUJK (Ijin Usaha Jasa Konstruksi) dari pemerintah. Ini adalah langkah yang beresiko dalam proses tender bagi kontraktor terutama pemula. Perusahaan dengan profil yang terendah tidak akan mendapatkan SBU dan IUJK, sehingga tidak memenuhi syarat untuk memasukkan penawaran dalam tender pemerintah.

Persyaratan ini mempengaruhi orangorang dalam industri konstruksi untuk melakukan kecurangan dengan tidak memberikan keterangan yang jelas dan benar mengenai kondisi perusahaannya. Sebagai contoh, keberadaan ahli teknik/engineering experts merupakan hal penting pada pengajuan SBU di LPJK. Perusahaanperusahaan yang tidak memiliki insinyur teknik yang memadai kemudian memanipulasi data ketika mengajukan sertifikasi di LPJK, sehingga bisa mendapatkan SBU dari pemerintah dan dapat ikut dalam tender. Praktek seperti ini tentu saja melanggar peraturan dan jika diketahui akan berakibat pada tuntutan hukum dan atau dicatat dalam daftar hitam (black list) sebagai perusahaan bermasalah.

Bagaimanapun, perusahaan akan mencari cara untuk dapat mengikuti proses tender. Setiap tahunnya Pemerintah Indonesia akan mengeluarkan daftar proyek yang akan dilelangkan lewat pemberitaan di media massa. Kontraktor akan mengajukan penawaran berdasarkan nilai proyek yang dikeluarkan oleh owner/bowheer/pemerintah dalam owner estimate (OE), dan besarnya penawaran kontraktor disebut engineering estimate (EE). Dalam tender kompetitif, nilai EE harus berada di bawah nilai OE. Ini merupakan prinsip dari tender konstruksi di Indonesia. Pada akhir proses pelelangan, tiga nilai EE terendah akan menjadi calon 
pemenang tender.

Prinsip ini membentuk prilaku baru bagi kontraktor. Ketika mereka mempersiapkan proposal penawaran, kontraktor terpaksa membuat $\mathrm{RAB}$ dengan menekan nilai keuntungan. Artinya modal akan sangat terbatas sehingga upaya kontraktor untuk menyelesaikan proyek dengan baik akan terganggu. Praktek kecurangan berkenaan dengan hal ini adalah nepotisme dan atau dengan mengatasnamakan kepentingan golongannya. Banyak perusahaan yang seringkali memenangkan tender karena faktor 'saling kenal'(terselubung) atau politik. Dengan iming-iming pembagian keuntungan, berbagai oknum perusahaan akan terpancing untuk mengurangi profit marginnya demi memenangkan tender. Biasanya praktek seperti ini akan berimbas kepada pengurangan mutu pekerjaan, yang ujungujungnya juga akan menyebabkan kegagalan perusahaan ketika ada temuan dari pejabat berwenang sehingga sering perusahaan masuk daftar bermasalah dan tidak dapat lagi mengikuti tender pada periode berikutnya.

Penggunaan uang muka dalam prakteknya di Indonesia sering disalahgunakan oleh kontaktor. Berdasarkan prosedur tender di Indonesia, seperti tercantum dalam Perpres No. 54/2010, pemenang tender akan mendapat uang muka sebesar $15 \%$ sampai dengan $20 \%$ dari total nilai kontrak. Uang muka diperuntukkan sebagai modal awal mengerjakan pekerjaan proyek. Namun kebanyakan kontraktor menggunakan uang muka untuk membeli barang mewah dan barang-barang lain yang tidak berhubungan dengan pekerjaan proyek dengan tujuan memperlihatkan bonafiditas. Cohen (1973) sebagaimana dikutip oleh Al Hallaq (2003) menuliskan salah satu gejala kegagalan dalam usaha konstruksi adalah "put prestige above profit" (meletakkan status kekayaan di atas keuntungan yang bisa diperoleh dari pekerjaan). Akibatnya, untuk memenuhi kebutuhan terhadap kekurangan modal awal, kontraktor mengambil pinjaman dari bank dengan bunga yang tinggi.

Selanjutnya, kesalahan manajemen pada pengendalian aliran kas dan tidak adanya departemen keuangan pada perusahaan konstruksi membuat kontraktor kesulitan mengendalikan aliran kas yang sangat cepat selama masa pelaksanaan. Namun sayangnya, sistem manajemen keuangan yang biasa terdapat dan umum digunakan pada organisasi fungsional selama ini tidak terlalu tepat digunakan pada perusahaan konstruksi (Peterson, 2005; Adrian, 1986) seperti dijelaskan oleh Ssgawa-Kaggwa (2008).

Kurangnya kontrol terhadap aliran kas akan menghantarkan pada kegagalan finansial dan menyebabkan turunnya nilai berbagai aset perusahaan, seperti turunnya nilai tenaga kerja (gaji dan kompensasinya), berhubungan dengan nilai pesanan yang berfariasi, biaya perawatan peralatan dan operasinya, pemborosan bahan-bahan, dan evaluasi keuntungan pertahunnya (Enshassi, 2006).

Ketika hal-hal tersebut terjadi, 
kontraktor akan kehilangan kemampuan untuk menyelesaikan proyek dengan baik. Biasanya jika kontraktor tidak dapat menyerahkan pekerjaan sesuai kontrak, sebagai resiko yang harus dihadapinya dan ini sering terjadi, kontraktor akan lari dari tanggungjawabnya, meninggalkan proyeknya terbengkalai setelah uang muka dan sebagian termjin sudah diterima.

Perusahaan akan masuk dalam black lists dan akan sulit untuk mengikuti penawaran pada tahun berikutnya. Dengan kata lain, insolvency terjadi. Orang atau organisasi yang mengalami insolvency akan mendirikan perusahaan baru, dengan nama baru, dan figure baru sehingga dapat memulai segalanya dari awal lagi. Ini sering terjadi di Indonesia dan harus segera dicarikan solusinya agar iklim industri konstruksi menjadi lebih sehat.

\section{Bagaimana menghindari Insolvency?}

Balcaen dan Ooghe (2006) menulis bahwa sebuah model yang dapat memprediksi sebuah kegagalan pada perusahaan sangat penting diterapkan terutama dalam menilai kondisi keuangan sebuah perusahaan. Mereka mengatakan bahwa ".... a developer is advised to take an active interest in the works so that it is alerted to any problems at an early stage and able to respond to these appropriately," (terjemahan: "sebuah perusahaan pembangunan disarankan untuk terlibat aktif dalam pekerjaannya sehingga mereka (pen: direksi perusahaan) akan segera mengetahui jika terjadi masalah pada tahap awal pekerjaan dan mampu merespon masalah tersebut dengan lebih baik") (Bell, 2008).

Berdasarkan hal tersebut di atas, maka penelitian untuk memprediksi kebangkrutan pada perusahaan konstruksi perlu dilakukan (Wong, 2010). Wong mengatakan bahwa adalah sangat penting untuk mengenal dan mengetahui gejala kegagalan pada perusahaan pada kesempatan paling dini. Dengan pengetahuan ini, maka pertolongan dapat segera diberikan baik dana maupun teknis.

Untuk memprediksi kegagalan ini telah dipersiapkan berbagai model termasuk analisa rasio, analisa multiple discrimination, model conditional probability dan subjective assessment.

\section{z-Score System}

Salah satu pionir yang menemukan model prediksi kegagalan bisnis adalah Prof. Edward Altman. Pada tahun 1968, Altman memperkenalkan sebuah model statistik untuk memprediksi kegagalan bisnis. Model yang ditemukan Altman ini dikenal dengan nama Z-Score dan dapat dijelaskan dalam rumus berikut ini (Creditguru, 2014):

$$
Z=3.3 A+0.9 B+0.6 C+1.2 D+1.4 E
$$

Dimana:
$\mathrm{A}=$ Earning Before Iinterest and Taxes/Total Assets
$\mathrm{B}=$ NET Sales/Total Assets
$\mathrm{C}=$ Market value of equity/total liability
$\mathrm{D}=$ Working Capital/Total Assets
$\mathrm{E}=$ Retain earning/total assets 
Penjelasan dari Z-Score adalah sebagai berikut:

Z-Score Above 3.0 - berdasarkan data finansial saja perusahaan dalam kondisi aman.

Z-Score Between 2.7 and 2.99 - Peringatan bagi perusahaan. Dalam zona ini perusahaan harus waspada dan melakukan perbaikan segera.

Z-Score Between 1.8 and 2.7 Kemungkinan besar perusahaan akan bangkrut dalam 2 (dua) tahun operasi sejak dilakukan penilaian finansial. Z-Score Below 1.80 - peluang terjadinya kehancuran finansial sangat tinggi.

Meskipun model ini tidak dibuat untuk perusahaan konstruksi, namun masih bisa digunakan pada perusahaan konstruksi yang memiliki nilai asset yang hampir sama dengan perusahaan dimana model ini dikembangkan. Model ini dianggap mampu dan merupakan indikator yang bagus untuk memperkirakan kondisi perusahaan dua sampai tiga tahun setelah analisa dilakukan.

\section{PEMBAHASAN}

Competitive tendering bisa dianggap sebagai salah satu penyebab utama dari kegagalan bisnis (insolvency) di Indonesia, walaupun akar permasalahan selalu berasal dari dalam perusahaan sendiri. Dari diskusi di atas, sudah menjadi hal yang semestinya bagi perusahaan konstruksi untuk mengikuti peraturan pemerintah dengan baik dan jujur, terutama dalam prosedur tender yang sudah ditetapkan oleh pemerintah.
Pertama, segala bentuk praktik kecurangan meskipun sering terjadi dalam proses tender untuk menang dalam tender adalah tidak benar. Oleh karenanya, monitoring dan evaluasi baik dari dalam dan luar perusahaan harusnya dilaksanakan oleh pihak yang berwenang (authority). Sistem yang efisien di LPJK dan panitia lelang sangat penting untuk memastikan proses tender berjalan dengan semestinya seperti diamanatkan dalam Perpres No. 54/2010.

Kedua, faktor finansial pada perusahaan harus dapat dikendalikan dengan baik, atau kegagalan akan mengancam keberlangsungan perusahaan. Oleh karenanya, sekecil apapun perusahaan harus memiliki bagian keuangan untuk mengendalikan aliran kas yang sangat cepat selama melakukan pekerjaan proyek konstruksi.

Ketiga, kegagalan seharusnya dapat diprediksi lebih awal. Model z-Score dapat digunakan pada perusahaan konstruksi di Indonesia, dengan mengumpulkan seluruh data yang diperlukan dan dibutuhkan dalam model tersebut. Ketika hasil perhitungan diperoleh, perusahaan akan mengetahui aspek apa saja yang harus menjadi perhatian utama untuk diperbaiki agar mendapatkan batas aman dalam z-score.

Tulisan ini memiliki keterbatasan dalam menampilkan data dan contoh kasus pada industri di Indonesia., karena belum ditemukan penelitian untuk masalah insolvency pada perusahaan konstruksi di dalam negeri sendiri. Literatur berasal dari paper luar negeri yang boleh jadi kasus per 
kasus memberikan fakta yang berbeda dari kondisi di Indonesia. Oleh karena itu, penyebab utama kegagalan yang dijelaskan dalam tulisan ini kemungkinan bukan faktor utama penyebab insolvency pada perusahaan konstruksi di Indonesia. Walaupun demikian, fakta menunjukkan bahwa analisa yang dipaparkan mengandung kebenaran.

Batasan lain dalam tulisan ini adalah kurangnya data atau informasi tentang kegagalan perusahaan-perusahaan yang pernah terjadi di Indonesia sangatlah terbatas, sehingga menemukan sumber data tentang pemecahan masalah menjadi lebih sulit dilakukan.

\section{PENELITIAN LEBIH LANJUT}

Industri konstruksi masih merupakan sektor prioritas di negara berkembang seperti Indonesia, sehingga penelitian lebih jauh tentang industri ini sangat penting untuk memecahkan berbagai masalah dan persoalan di dalamnya. Fakta bahwa ini adalah bisnis paling beresiko dibandingkan dengan bisnis lainnya, menuntut pelaku bisnis dan pemerintah untuk lebih tanggap terhadap berbagai karakter dan keadaan yang mungkin dapat menyebabkan kebangkrutan perusahaan (insolvency).

Manajemen perusahaan konstruksi menjadi sangat penting untuk ditelaah dalam upaya mengetahui faktor apa saja dalam perusahaan yang cukup rawan terhadap kegagalan kerja proyek. Selain itu, kemampuan perusahaan untuk mengenal figure dirinya lebih baik, membuat pendataan terhadap kebutuhan perusahaan dan proyek yang sedang dikerjakan sebagai langkah awal pengendalian corporate sustainability dari berbagai metode pengendalian asset serta keuangan (misalnya Z-Score) juga sangat menarik untuk dikupas dalam sebuah penelitian menyeluruh.

Penelitian lebih jauh mengenai bidang konstruksi akan sangat membantu dalam peningkatan pengetahuan bagi perusahaan maupun orang-orang yang tertarik bekerja di industri ini. Lebih daripada itu, kebutuhan akan referensi, data literatur dan bahan bacaan bagi mahasiswa khususnya prodi Teknik Sipil ataupun Industri akan diperkaya dengan adanya pengembangan penelitian pada manajemen perusahaan konstruksi di Indonesia.

\section{KESIMPULAN DAN SARAN}

Dari pembahasan di atas, maka dapat diambil kesimpulan sebagai berikut : Proses tender yang bersifat kompetitif bisa jadi penyebab kegagalan bisnis beberapa perusahaan konstruksi yang masih belum kuat di Indonesia. Namun, penyebab sebenarnya adalah sangat kompleks, sehingga harus dicari solusi yang dapat menyelesaikan permasalahan dari faktor penyebabnya sendiri. Faktor-faktor itu dapat berasal dari luar ataupun dalam perusahaan sendiri, sedangkan tender menjadi ujung tombak yang menentukan kualitas perusahaan konstruksi ketika prosedur tidak dilaksanakan dengan baik dan kemampuan perusahaan yang tidak memadai dipaksa untuk menjadi 
pemenang tender. Lebih jauh lagi, perilaku orang-orang yang bekerja di industri ini pun harus dapat diubah menjadi lebih baik dan lebih jujur. Dalam industri ini kejujuran sangat penting.

Peraturan yang dibuat oleh pemerintah sebenarnya sudah dapat menampung seluruh prosedur dengan baik dan lengkap dan kontraktor harus mampu mengikuti prosedur ini dengan bertanggungjawab. Walaupun bahaya insolvency itu membelit dan mengancam perusahaan, namun sebenarnya kontraktor masih bisa memprediksi sejak awal sebelum itu benar-benar terjadi, sehingga ancaman insolvency dapat ditanggulangi secara lebih dini.

\section{DAFTAR PUSTAKA}

Ab Halim, M. S., Jafar, M., Osman, O., Akbar, S., 2010, "the Contracting Firm's Failure and Financial Related Factors: A Case Study of Malaysian Contracting Firm", International Research Online Journal of Finance and Economic Issue 52 (2010). Diunduh pada 14 Agustus 2011, dari http://www.eurojournal.com/irjfe_5 2_03.pdf

Al Hallaq, K. A. R., 2003, "Causes of Contractor's Failure in Gaza Strip", Islamic University of Gaza, diunduh pada September 2011 dari http://www.library.iugaza.edu.ps/Th esis/57770.pdf

Arain, F. M., 2008,"Causes of Insolvency and Unethical Practices of Contractors in Pakistan Construction Industry", Journal of International Conference on Building Education and Research (BEAR) 'Building Resilience', 1115 Februari 2008, vol. 131 pp.1246-1262, diunduh pada 26 September 2011 dari http://www.irbnet.de/daten/iconda/ CIB11455.pdf

Balcaen, S., dan Ooghe, H., 2004, “35 Years of Studies on Business Failure: an Overview of the Classical Statistical Methodologies and Their Related Problems", Journal of Vlerick Leuven Gent Working Paper vol. 15 pp.6, diunduh pada 29 September 2011 dari http://www.vlerick.be/en/2665VLK/version/default/... vlgms-wp2004-15.pdf

Bell, A., 2008, "The Implication of Insolvency on Construction Projects", 1 Oktober 2008, Journal of Insolvency Law Forum, diunduh pada 30 September 2011 dari http://www.insolvencylawforum.co. uk/index.php?option=com_content $\&$ view $=$ article $\& i d=167:$ the implication-of-insolvency-onconstructionprojects\&catid $=8$ :opinionposts\&Itemid $=20$

CreditGuru, 2014, Measuring the 'FiscalFitness' of A Company: The Altman 
Z-Score, diunduh pada 20 Januari 2014 dari

http://www.creditguru.com/CalcAlt Z.shtml

Enshassi, A., Al Hallaq, K., Muhamed, S., 2006, "Causes of Contractors Business Failure in Developing Countries: The Case of Palestine", Journal of Construction in Developing Countries, Vol. 11 No. 2, Universiti Sains Malaysia. Diunduh pada 14 Agustus 2011 dari http://web.sum.my/jcdc/input/JCDC $\% 20$ VOL\%2011(2)/1\%20Adnan\%2 $0(p .1-14) . p d f$

Perpres RI, 2010, Peraturan Presiden tentang Pengadaan Barang dan Jasa No. 54 tahun 2010, Jakarta diunduh pada 26 September 2011 dari http://www.inkindo.org/Perpres-54Tahun-2010.pdf
Saputra, A., 2011, “Terlilit Utang US\$ 7,6 Juta, Istaka KArya Pailit”, Detik Finance, 6 May 2011, diunduh pada 28 September 2011 dari http://us.detikfinance.com/read/201 1/05/06

Ssgawa-Kaggwa, J., 2008, “Adequacy of Project Based Financial Management Systems of Small and Medium Construction Enterprises in Botswana", University of South Africa (Unisa), Johannesburg, South Africa, diunduh pada 26 September 2011 dari http://uir.unisa.ac.za

Wong, J. M. W., NG, S. T., 2010, "Company Failure in the Construction Industry: a Critical Review and Future Research Agenda”, FIG Congress 2010, Sydney, Australia, diunduh pada 14 Agustus 2011 dari http://hdl.handle.net/10722/127294 